\title{
Membangun Kohesi Sosial dalam Masyarakat Majemuk di Tengah Tantangan Pandemi
}

\author{
Ignatius Ismanto \\ Universitas Pelita Harapan \\ ignatius.ismanto@uph.edu
}

\begin{abstract}
Abstrak
Pandemi Covid 19 merupakan isu global dan menjadi ancaman keamanan non-tradisional bagi Indonesia. Pemerintah Indonesia telah menetapkan kebijakan Pembatasan Sosial Berskala Besar (PSBB) sebagai salah satu upaya menanggulangi bencana nasional itu. Kebijakan PSBB juga menjadi acuan bagi kegiatan social bagi warga komunitas gereja Lingkungan Santa Theresia, Paroki Santa Maria Regina, Bintaro Jaya. Namun, selama masa pandemi itu warga komunitas tetap ingin merawat kohesi sosial yang selama ini telah mereka bina. Sehubungan itu dirancang kegiatan-kegiatan yang membuka keterlibatan warga dan sekaligus kegiatan itu juga dapat membawa manfaat konkrit bagi warga masyarakat yang lebih luas. Gerakan "Mari Peduli" menjadi sarana bagi warga dalam ikut serta membangun kohesi social, memperkuat identitas masyarakat yang majemuk dan sekaligus dapat dipandang sebagai salah satu strategi keterlibatan masyarakat dalam ikut serta mengatasi ancaman keamanan non-tradisional.
\end{abstract}

Kata kunci: ancaman keamanan non-tradisional, kohesi sosial, dan identitas masyarakat majemuk

\section{PENDAHULUAN}

"Mari Peduli" merupakan program kepedulian yang berkembang di tengah tantangan meluasnya penyebaran virus Corona 19. Program ini dikembangkan oleh warga komunitas gereja Lingkungan Santa Theresia. Lingkungan Santa Theresia merupakan salah wilayah dari gereja Paroki Santa Maria Regina, Bintaro Jaya. Pandami telah membawa sejumlah keprihatinan kehidupan sosial masyarakat, termasuk bagi waga komunitas Lingkungan Santa Theresia. Pertama, masa pandemic telah merubah kegiatankegiatan rutin yang selama telah dilakukan.
Sejumlah kegiatan kini dilakukan dengan caracara yang baru, yaitu secara virtual. Keterbatasan akses terhadap media komunikasi virtual juga dapat menjadi kendala bagi sejumlah warga agar dapat ikut terlibat dalam kegiatan virtual itu. Masa pandemic dirasakan tantangan dalam menjalin komunikasi. Kedua, pandemic juga dirasakan telah membawa kesulitan yang dialami warga komunitas maupun warga masyarakat sekitar. Keluarga yang kehilangan pekerjaan mulai kesulitan finansial untuk menopang kehidupan sehari-hari. Keluarga yang anggota keluarganya terpapar Virus Corona juga mengalami tantangan hidup yang semakin berat.

Ekonomi, Sosial, dan Budaya 
Program kepedulian ini secara internal dirancang untuk merawat hubungan di kalangan komunitas yang menghadapi keterbatasan untuk menjalin komunikasi. Secara eksternal, program kepedulian dimaksudkan untuk membuka kepedulian social bagi komunitas Lingkungan Theresia terhadap masyarakat yang lebih luas, yang menghadapi kesulitan menghadapi masa Pandemi.

Lingkungan Santa Theresia terdiri dari 58 Kepala Keluarga dan mereka itu sebagian besar tinggal perumahan Bintara Jaya, khususnya meliputi: klaster Kasuari, klaster Kasturi dan Klaster Graha Taman, Bintaro Jaya, Sektor 9. Komunitas Lingkungan Santa Theresia juga merupakan bagian dari komunitas masyarakat yang lebih luas, yang berdomisili di Perumahan Bintara Jaya. Komunitas gereja Katholik Lingkungan Santa Theresia juga menjadi identitas keanakaragaman masyakat Bintaro Jaya. Dilihat dari populasinya, jumlah ummat Katholik di Klaster Kasuari, misalnya, diperkiraan kurang lebih 15 persen, yaitu 32 Kepala Keluarga dari sekitar 200-an Kepala Keluarga. Namun, jumlah prosentasi ini sama sekali bukan menjadi penghalang bagi komunitas gereja Lingkungan Santa Thersia untuk terlibat dalam kegiatankegiatan social dalam komunitas sosial yang lebih luas, yaitu komunitas warga Bintaro Jaya. Warga Lingkungan Santa Theresia ikut aktif terlibat dalam kepengurusan, baik di tingkat Rukun Tetangga dan Rukun Warga. Demikian pula warga Lingkungan Santa Theresia yang tinggal di klaster-klaster perumahan Bintaro Jaya lainnya. Warga Lingkungan Santa Theresia juga selalu aktif terlibat dalam berbagai kegiatan social di lingkungan RT/RW masing-masing, seperti: Program Kesehatan, Program Kebersihan Lingkungan, kegiatan Perayaan Peringatan Hari Kemerdekaan, Perayaan Halal bi Halal yang melibatkan seluruh warga masyarakat di setiap kluster masing-masing.
Program Mari Peduli, karena itu, dapat menjadi sarana bagi umat gereja untuk terlibat bersamasama dengan masyarakat yang lain dalam ikut serta mendukung penanggulangan ancaman Bersama, yaitu menghadapi meluasnya penyebaran Virus Corona. Laporan ini menggambarkan kegiatan bagaimana Program Mari peduli yang dilaksanakan, khususnya pada lingkungan perumahan klaster Kasuari, Bintara Jaya.

Mari Peduli merupakan gagasan yang awalnya berkembang dari pertemuan-pertemuan warga secara virtual di tengah ancaman meluasnya Virus Corona menjelang pertengahan Maret 2020. Gagasan itu lebih didorong oleh semangat untuk berbuat sesuatu yang bermanfaat bagi orang lain di tengah berbagai kesulitan yang terjadi saat itu. Gagasan yang dinamakan Mari Peduli inilah yang akhirnya menginspirasi warga gereja Lingkungan Santa Theresia dalam membuat program dan menjalankan kegiatankegiatannya. Apa tujuan pencanangan Program Mari Peduli ini? Setidak-tidaknya ada 2 tujuan yang hendak diwujudkan dari program yang dicanangkan saat masyarakat Indonesia menghadapi meluasnya ancaman wabah virus Corona.

Pertama, yaitu program ini diharapkan menjadi sarana untuk tetap menjalin komunikasi warga Lingkungan Santa Theresia. Kebijakan PSBB yang ditetapkan pemerintah telah mendorong sejumlah aktivitas atau kegiatan dikerjakan dari rumah. Sejumlah kantor atau perusahaan mendorong karyawan mereka untuk berkerja dari rumah, atau yang dikenal denga singkatan WFH, Work from Home. Demikian pula kegiatan yang sifat kerumunan untuk sementara tidak diperkenankan. Gereja Katholik Santa Maria Regina juga tidak menyelenggarakan pelayanan yang sifatnya mengundang kerumunan, seperti pelayanan Missa Kudus selama masa PSBB itu.

Ekonomi, Sosial, dan Budaya 
Pelayanan Misa Kudus diselenggarakan secara virtual. Menanggapi kebijakan yang ditetapkan pemerintah tentang PSBB itu, Gereja Katholik termasuk Lingkungan Santa Theresia membangun media komunikasi baru dengan mengandalkan jaringan internet, atau yang lebih dikenal dengan istilah komunikasi secara virtual. Berbagai platform komunikasi yang selama ini digunakan adalah WA Grup serta Zoom. Kedua platform ini dinilai mudah diakses oleh warga. Program Mari Peduli di tengah meluasnya wabah Virus Corona karena ini diharapkan untuk tetap merawat jaringan komunikasi antar warga yang selama ini telah dibangun. Sehubungan dengan itu, program Mari Peduli diharapkan menjadi sarana untuk membangun apa yang disebut dengan konsep "kohesi social" di antara warga Lingkungan Santa Theresia, Bintaro Jaya.

Kedua, yaitu program Mari Peduli yang dikembangkan oleh Lingkungan Santa Theresia ini juga menjadi sarana bagi warga Katholik untuk ikut serta berpartisipasi dan bekerjasama dengan organisasi, komunitas-komunitas lainnya, di tengah tantangan mereka bersama, dalam mengatasi meluasnya wabah virus Corona. Wabah Covid-19, yang mulai meluas di Indonesia sejak pertengahan Maret 2020, telah membawa dampak sosial-ekonomi yang luas bagi masyarakat, seperti: meningkatnya jumlah pemutusan hubungan kerja, meluasnya pengangguran serta meningkatnya jumlah kemiskinan. Dampak itu-pun mulai dirasakan oleh warga masyarakat Tangerang Selatan pada umumnya dimana Lingkungan Santa Theresia berada. Saat itu juga telah berkembang berbagai lembaga, institusi serta komunitas yang berperan aktif dalam mengatasi wabah Corona. Pada lingkungan masyarakat warga Perumahan Kluster Kasuari, misalnya, dimana laporan kegiatan ini difokuskan, lembaga atau institusi itu adalah RT dan RW, serta Puskesmas Kecamatan Pondok Pucung. Bersama lembaga, institusi atau komunitas warga itu-lah komunitas Lingkungan
Theresia bekerjasama dalam mengatasi meluasnya pandemi.

\section{METODE}

Mendorong partisipasi aktif warga komunitas gereja Lingkungan Santa Theresia untuk terlibat dalam berbagai kegiatan dan ikut serta terlibat dalam forum-forum kegiatan yang melibatkan berbagai aktor dalam mengatasi ancaman pandemi menjadi kunci utama dalam mewujudkan tujuan program Mari Peduli. Aktoraktor lain, selain komunitas Lingkungan Santa Theresia, yang berperan aktif dalam kegiatan untuk mengatasi perluasan wabah pandemi dalam laporan ini adalah komunitas Rukun Warga (RW) di Perumahan Kluster Kasuari, termasuk komunitas Rukun Tetangga (RT) yang berada dalam koordinasi RW Kasuari.

Membangun program atau forum yang terbuka bagi warga gereja Lingkungan Santa Theresia juga menjadi sarana dalam mewujudkan gagaan untuk membangun kohesi social serta memperkuat kelangsungan identitas masyarakat yang majemuk. Sejumlah forum atau kegiatan dalam menfasitasi kegiatan internal warga Lingkungan Santa Theresia itu selama masa pandemic itu adalah: Tepas (Temu Pastor), Doa Bersama, dan Ayo Berbagi. Seluruh aktivitas program atau forum-forum itu diselenggarakan dengan mentaati kebijakan PSBB yang ditetapkan pemerintah. Di samping forum-forum yang dibanguna oleh Lingkungan Santa Theresia, juga ada program-program atau forum-forum yang dibangun oleh RW yaitu: Program Kesehatan, Program Peduli Kasih.

Program peduli social yang digagas oleh Lingkungan Santa Theresia ini mulai dijalankan sejak awal April hingga akhir Juli 2020. Gagasangagasan umumnya dibicarakan dalam pertemuanpertemuan virtual. Sedang realiasi di lapangan 
tidak semua bisa terlibat, karena kendala phisik. Realiasi di lapangan dilakukan oleh mereka yang masih muda atau secara phisik memungkinkan, serta dibantu oleh pihak-pihak lain.

\section{HASIL DAN PEMBAHASAN}

\section{III.1. Membangun Kohesi Sosial}

Pandemi Covid-19 dapat dipandang sebagai bentuk ancaman keamanan non-tradisional. Apa arti ancaman keamanan non-tradisional, dan bagaimana mengatasi ancaman keamanan nontradisional merupakan isu yang menarik. Dalam Studi Hubungan Internasional dikenal ada dua bentuk ancaman keamanan, yaitu: ancaman keamanan tradisional dan ancaman keamanan non-tradisional. Kedua bentuk ancaman keamanan ini sangat berbeda secara substansial dan karenanya juga cara untuk mengatasinya. Ancaman keamanan tradisional merupakan ancaman yang bersumber dari kekuatan militer. Siapakah yang paling terancam dari keamanan non-tradisional itu?. Negara menjadi sasaran utama dari ancaman keamanan non-tradisional. Isu keamanan yang berasal dari ancaman kekuatan militer ini juga sering disebut sebagai ancaman keamanan negara, dan karena itu peran negara merupakan aktor utama dalam mengatasi ancaman keamanan ini. Ancaman keamanan tradisional membutuhkan pendekatan keamanan negara untuk mengatasinya, atau yang lebih dikenal dengan pendekatan state-scurity approach. Sedangkan keamanan non-tradisional yaitu ancaman keamanan yang bersumber dari luar militer. Sumber-sumber ancaman di luar militer itu antara lain, seperti: krisis ekonomi, bencana alam, kemiskinan, penyebaran penyakit. Siapakah yang menjadi ancaman utama dari keamanan non-tradisional itu?. Ancaman utama yang menjadi isu keamanan non-tradisional itu adalah manusia. Sehubunan dengan itu pendekatan keamanan manusia (human security) menjadi isu utama dalam mengatasi ancamanan keamanan non-tradisional.

Fitrah (2015) menjelaskan sejumlah sumber keamanan manusia itu, yaitu keamanan ekonomi (economic security), keamanan pangan (food security), keamanan kesehatan (health security), keamanan lingkungan hidup (environment security), keamanan personal (personal security), keamanan komunitas (community security), dan keamanan politik (political security). Perluasan wabah virus corona merupakan salah satu bentuk sumber ancaman bagi keamanan manusia dan karena itu dapat dikategorikan sebagai ancamanan keamanan non-tradisional. Mengapa mengatasi isu keamanan dengan membedakan sumber-sumber ancaman itu penting? Kedua bentuk ancaman itu pada hakekatnya memerlukan cara yang berbeda untuk mengatasinya. Isu keamanan tradisional lebih menekankan pada keamanan negara, dan karena itu menuntut peran negara yang utama dalam mengatasinya. Sedangkan keamanan nontradisional, Susetyo (2008) menjelaskan bahwa isu keamanan itu lebih menekankan pada kepentingan keamanan bagi actor-aktor bukan negara (non-state actors). Sehubungan dengan itu keterlibatan masyarakat sangat dipenting dalam mengatasi isu keamanan non-tradisonal itu. Dalam mengatasi isu keamanan nontradisional memerlukan pendekatan yang lebih komprehensif, artinya menuntut keterlibatan yang lebih luas, tidak hanya negara (pemerintah) tetapi juga menuntut keterlibatan civil society dalam mengatasi isu keamanan itu.

Berikut ini adalah sejumlah program atau kegiatan yang dirancang oleh warga Lingkungan Santa Theresia di tengah masa pandemi. Program-program atau kegiatan ini dapat dipandang sebagai upaya untuk ikut serta mengatasi penyebaran virus Corona. Mengapa demikian? Karena kegiatan-kegiatan dilakukan dengan mentaati protocol kesehatan. Protokol

Ekonomi, Sosial, dan Budaya 1053 
kesehatan merupakan kebijakan yang ditempuh pemerintah dalam mencegah meluasnya penyebaran virus Corona. Di samping itu, kegiatan yang melibatkan partisipasi warga Lingkungan Santa Theresia ini dipandang menjadi sarana penting dalam merawat hubungan yang telah mereka bangun selama ini, bahkan kegiatan-kegiatan itu menjadi wahana dalam membangun kohesi social yang lebih baik. Kohesi social ini meliputi terbangunnnya rasa saling percaya dan tumbuhnya rasa saling kepedulian di antara warga.

\section{a. Kegiatan Rohani secara Virtual.}

Doa Bersama merupakan salah satu kegiatan rohani bagi kalangan umat Katholik, termasuk umat Katholik Lingkungan Santa Theresia yang terstruktur. Kegiatan itu tetap berlangsung sekalipun saat pandemi mulai meluas yaitu pertengahan bulan Maret, bersamaan dengan masa persiapan Pra Paskah. Doa Bersama biasanya diselenggarakan bagi warga Lingkungan Theresia dalam bentuk: Doa Jalan Salib dan Doa Rosario. Sebelum masa pandemic, kegiatan doa bersama itu diselenggarankan secara bergilir dari satu keluarga ke keluarga lain. Doa Jalan Salib diselenggarakan saat persiapan merayakan Paskah, yaitu bulan Maret hingga April. Sedangkan Doa Rosario diselenggarakan setiap minggu sekali selama bulan Mei. Selama masa pandemi untuk menyelenggarakan kegiatan doa Bersama tidak lagi memungkinkan dilakukan dengan cara-cara seperti sebelumnya, yaitu berkumpul dalam salah satu keluarga. Namun, kegiatan doa Bersama dilakukan secara virtual. Ada sejumlah pelajaran yang menarik dari pelaksanaan doa Bersama secara virtual selama masa pandemic itu. Pertemuan Doa Bersama secara virtual membuka kesempatan bagi setiap invidu untuk mengungkapkan pengalaman yang mereka alami, terlebih di tengah kesulitan masa pandemi. Pertemuan Doa Bersama juga menjadi sarana bagi setiap orang untuk melatih menjadi 'pendengar yang baik'. Pendengar yang baik dalam artian ini diartikan sebagai seorang yang dapat menyimpan kerahasian yang diceritakan atau disharingkan seseorang dalam pertemuan doa. Pendengar yang baik juga diartikan sebagai orang yang tak mudah terpancing untuk mengomentari, apalagi menghakami pengalaman yang disharingkan orang lain. Pertemuan Doa Bersama yang dilakukan secara virtual ini menjadi sarana untuk mewujudkan kerinduan warga, karena situasi yang tidak mudah lagi bertemu secara phisik. Kesempatan bagi warga untuk saling menanyakan bagaimana perkembangan mereka masing-masing dalam masa-masa yang sulit itu. Pertemuan doa Bersama ini juga menjadi sarana untuk membangun rasa saling percaya dalam kelompok.

Rasa kerinduan untuk saling bertemu antar warga Lingkungan Santa Theresia itu tercermin dari tingginya keterlibatan mereka dalam pertemuan doa Bersama secara virtual. Rata-rata tingkat kehadiran setiap pertemuan doa Bersama itu mencapai $70-80$ persen. Mereka yang berhalangan umumnya memberi tahu melalui WA Group.

\section{b. Tepas}

Tepas merupakan singkatan dari "Temu Pastor". Forum ini juga menjadi sarana pertemuan bagi warga Lingkungan Santa Theresia. Bila Doa Bersama merupakan forum pertemuan yang banyak diisi oleh kegiatan rohani, maka Tepas merupakan forum yang lebih santai dari forum Doa Bersama. Forum Tepas, sesuai singkatannya, selalu dihadiri oleh pastor-pastor Paroki Gereja Santa Maria Regina. Forum Tepas ini juga dilakukan secara virtual dan diselenggarankan setiap 6 bulan. Apa yang dibahas dalam Tepas? Tepas membahas permasalahan-permasalahan

Ekonomi, Sosial, dan Budaya 1054 
yang dihadapi warga serta mencari jawaban atau solusi. Tepas juga menjadi ruang warga untuk bercanda bagi warga. Forum ini juga dapat menjadi wahana untuk melepaskan kerinduan terhadap anggota juga telah membuka inspirasi bagi kegiatan-kegiatan kepedulian bagi sesama, kepedulian terhadap masyarakat yang lebih luas, terlebih di tengah situasi yang sulit saat itu.

\section{c. Nasi Bungkus}

Salah satu bentuk kepedulian terhadap sesama dan masyarakat luas yang diwujudkan oleh warga Lingkungan Santa Theresia adalah membagikan nasi bungkus. Pembagian nasi bungkus ini diberikan kepada warga yang membutuhkan. Mereka umumnya adalah warga masyarakat yang mengalami kesulitan ekonomi. Pandemi telah membawa dampak yang luas bagi kehidupan ekonomi masyarakat, seperti: kehilangan pekerjaaan, kesulitan berusaha hingga kesulitan atau keterbatasan finansial untuk membiayai hidup layak sehari-hari. Pengadaan Nasi bungkus dikelola sendiri oleh warga lingkungan Santa Theresia, dan ada juga yang dikerjakan oleh pihak lain, umumnya mereka ini membuka usaha warung makan. Pembagaian nasi bungkus kepada masyarakat yang membutuhkan dilakukan oleh anggota warga Lingkungan Santa Theresia dengan tetap memperhatikan protocol kesehatan. Adapun pembiayaan kegiatan pengadaan nasi bungkus ini dikumpulkan dari donasi warga secara suka rela. Membagi-bagikan nasi bungkus bagi mereka yang membutuhkan ini menjadi upaya yang positif, terutama dalam menumbuhkan semangat kepedulian terhadap sesama. Upaya kegiatan sekecil apa-pun bila dilakukan dengan ketulusan hati diharapkan dapat membantu meringankan persoalanpersoalan di tengah kesulitan meluasnya pandemi.

\section{III.2. Memperkuat Indentitas Kemajemukan}

Masyarakat majemuk (pluralistic society) merupakan konsep yang awalnya diperkenalkan oleh seorang antropolog J.S Furnival dalam menggambarkan masyakat Indnesia selama masa masa colonial Hindi Belanda. Konsep ini juga banyak digunakan dalam menggambarkan masyarakat-masyarakat di Kawasan Asia Tenggara. Konsep masyarakat majemuk itu merupakan gambaran masyarakat yang terdiri dari dua atau lebih tatanan sosial yang berbeda, dan hidup secara berdampingan, namun tanpa adanya pembauran satu sama lain dalam suatu kesatuan politik. Smith (1965) lebih lanjut menjelaskan "a society in which people mix but do not combine" Setiap elemen masyarakat mempertahankan budaya dan Bahasa serta pemikiran atau cara pandang masing-masing. Mereka saling bertemu dalam bermasyarakat, namun mereka tidak membaur. Setiap elemen masyarakat mempertahankan ikatan social mereka masing-masing. Geetz lebih jauh menjelaskan bahwa ikatan-ikatan social itu dapat bersifat primordial, yaitu ikatan-ikatan social yang dibawa sejak seseorang dilahirkan.

Masyarakat Indonesia sebagai satu kesatuan entitas politik memiliki keragaman suku bangsa, agama, adat, dan kedaerahan. Keragaman itu juga seringkali dipakai untuk menggambarkan ciri masyarakat Indonesia yang bersifat majemuk. Suku bangsa, agama, adat serta kedaerahan itu yang dimaksudkan sebagai tatanan social oleh Furnival. Salah satu tantangan dalam masyarakat majemuk, sebagaimana dikemukakan oleh Lestari Moerdijat (2020); Harianto dkk (2017) adalah kerentanan masyarakat itu terhadap konflik. Artinya perbedaan etnis, suku, agama, adat - istiadat serta latar belakang social ekonomi berpotensi menjadi sumber konflik social. Apa masalahanya dengan keanekaragaman itu? 
Namun, keaneka-ragaman itu sendiri sejatinya bukan-lah sesuatu yang harus dikutuk, dihindari, disingkirkan atau dimusnahkan. Keanekaragaman juga sama sekali tidak bertentangan dengan nilai-nilai demokrasi. Pancasila yang menjadi dasar negara Republik Indonesia secara tegas memberikan pengakuan terhadap keanekaragaman itu. Tanggung-jawab kita semua untuk memelihara keragaman itu bagi kelangsungan negara dan bangsa Indonesia. Bagaimana menjadikan keaneka-ragaman itu sebagai sumber kekuatan itu merupakan upaya yang harus diperjuangkan. Praktek-praktek kehidupan bermasyarakat telah mengajarkan bahwa melembagakan institusi yang bersifat crosscutting affiliation, yaitu membangun institusi yang melibatkan keanggotaam dari berbagai elemen dalam masyarakat itu dipandang merupakan salah satu cara dalam mewujudkan kehidupan yang harmoni dalam masyarakat yang majemuk. Sehubungan dengan itu mendorong keterlibatan warga Santa Theresia dalam berbagai forum yang melibatkan keangotaan berbagai elemen masyarakat merupakan salah satu cara mewujudkan kehidupan social yang harmonis. Membangun keterlibatan warga Lingkungan Santa Theresia dalam berbagai forum dengan berbagai latar belakang keragaman etnis, suku bangsa, agama, serta adat istiadat kedaerahan itu juga dipandang dapat memperkuat demokrasi yaitu dengan mengakui keragaman, namun tetap satu, yaitu bangsa Indonesia.

Berikut ini adalah berbagai program atau kegiatan yang telah dikembangkan oleh komunitas lingkungan Rukun Warga (RW) Klaster Kasuari. Program dan kegiatan-kegiatan mempunyai arti yang penting karane menjadi sarana bagi warga Lingkungan Santa Theresia dalam menjaga keragaman serta memperkuat gagasan demokrasi.

\section{a. Program Kesehatan}

Salah satu program yang menarik pada lingkungan RW Kasuari di tengah meluasnya pandemi sejak Maret 2020 yaitu program kesehatan. Program kesehatan yang dikoordinasikan oleh RW ini melibatkan berbagai instansi pemerintah serta elemen masyarakat. RW Kasuari telah menjalin kerjasama dengan Puskesmas (Pusat Kesehatan Masyarakat), Kelurahan Pondok Pucung dalam penanganan Covid-19. RW dan didukung oleh seluruh RT telah menerbitkan buku panduan emergency tentang apa yang seharusnya dilakukan oleh warga bila mengalami sejumlah gejala terinfeksi Virus Corona, serta upaya-upaya pencegahnnya. WA Group yang berkaitan dengan Pencegahan Covid-19 juga telah dibentuk. Fasilitas-fasilitas publik untuk pencegahan Covid juga telah dibangun, seperti: tempat cuci tangan. Demikian pula telah ditetapkan pengaturan bagi pedagang sayur serta pedagang keliling yang masuk Komplek Kasuari. Kelembagaan kegiatan yang telah dibangun oleh RW ini menjadi sarana keterlibatan bagi warga Lingkungan Santa Theresia. Warga lingkungan Theresia sebagai bagian dari warga Lingkungan RW Kasuari ikut bersatu padu dalam upaya untuk memerangi perluasan pandemi, tanpa terkotakkotak oleh latar belakang agama, suku / etnis, serta latar belakang social-ekonomi mereka.

\section{b. Program 'Peduli Kasih'}

Program Peduli Kasih juga menjadi salah satu program menarik yang dikembangkan di tengah masa pandemi. Program ini dirancang untuk membantu mereka yang mengalami kesulitan ekonomi sebagai dampak pandemic. Mereka itu umumnya adalah tukang gojeg, tukang bangunan, pedagang keliling yang kurang beruntung sejak masa pandemi. Program peduli kasih diwujudkan dalam bentuk memberi bantuan finansial kepada keluarga yang secara ekonomi kurang mampu dan atau mengalami musibah, seperti: sakit atau

Ekonomi, Sosial, dan Budaya 1056 
pun meninggal selama masa pandemi. Selain pemberian bantuan finansial, program peduli kasih juga diwujudkan dalam kegiatan pembagian makan siang, yaitu nasi bungkus atau nasi kotak secara gratis. Penyediaan makan siang diserahkan pada sejumlah warung yang berlokasi di sekitar perumahan Bintaro Jaya. Melibatkan warung-warung makan dalam penyediaan nasi bungkus itu juga diharapkan agar dapat menghidupkan kegiatan ekonomi di kalangan sektor informal, sektor yang sangat terpukul dari dampak pandemic. Program Peduli Kasih didanai dari sumbangan warga secara sukarela. Dana dihimpun dengan pembukaan rekening bank dan didistribusikan melalui WA Group. Masyarakat warga Kasuari dapat mengetahui perkembangan tentang pemasukan serta pengeluaran setiap harinya melalui laporan yang disebarkan dalam WA Grup.

Program Peduli Kasih sesuai namanya berperan penting, terutama dalam menumbuhkan rasa kepedulian warga terhadap sesama. Menumbuhkan rasa kepedulian itu dibangun melalui semangat membantu sesame yang mengalami kesulitan, tanpa memandang latar belakang perbedaan ras, etnis, suku, agama, adatistiadat. Kepedulian terhadap mereka yang lemah atau mereka yang terpingirkan karena proses perubahan social merupakan salah satu nilai moral yang telah ditanamkan oleh generasigenerasi sebelumnya. Kepedulian terhadap sesame merupakan aspek yang penting dalam membangun solidaritas social. Solidaritas sosial ini merupakan perekat yang penting dalam mewujudkan persatuan dan kesatuan di kalangan masyarakat yang majemuk. Ben Anderson, seorang antropolog dan yang memperkenalkan konsep "imagined community" menyoroti melemahnya solidaritas social di tengah perubahan ekonomi Indonesia sebagai tantangan dalam merawat persatuan dan kesatuan bangsa Indonesia. Kiranya kegiatan Program Peduli Kasih yang dicanangkan oleh masyarakat warga
Kasuari itu dapat menjadi pelajaran yang berarti dalam menumbuhkan kembali solidaritas social, nilai yang sangat diperlukan dalam merawat kemajumukan masyarakat Indonesia.

\section{KESIMPULAN}

Memelihara keanekaragaman dari berbagai elemen masyarakat merupakan aspek yang penting bagi kekuatan serta kelangsungan demokrasi. Keaneka-ragaman itu dapat dipertahankan dengan mendorong tumbuhnya suatu masyarakat yang terbuka akan keragaman itu sendiri. Masyarakat yang terbuka atau sering juga dikenal dengan istilah masyarakat yang inclusive, yaitu masyarakat yang menerima dan mengakui keragaman sebagai realitas social, menjadi bagian yang tak terpisahkan bagi kelangsungan demokrasi. Kehadiran masyarakat Bintaro yang inclusive telah menjadi rumah yang damai bagi perkembangan komunitas warga Lingkungan Santa Theresia. Kegiatan-kegiatan yang diselenggarakan oleh warga Lingkungan Santa Theresia, baik secara internal maupun secara eksternal selama masa pandemic telah memberikan arti yang penting, khusus dalam membangun kohesi social maupun dalam ikut serta dalam merawat kemajemukan masyarakat Indonesia. Program dan kegiatan Lingkungan Santa Theresia merupakan langkah konkrit dalam menjaga kelangsungan masyarakat Indones yang 'bhineka tunggal ika', meskipun berbeda-beda tetapi tetap satu, yaitu masyarakat bangsa Indonesia.

\section{UCAPAN TERIMA KASIH}

Program dan kegiatan social Lingkungan Santa Theresia dapat diselenggarakan di tengah tantangan pandemic itu karena keterlibatan berbagai pihak. Untuk itu, kami selaku penulis laporan kegiatan itu, sekaligus menyampaikan terima kasih, kepada:

Ekonomi, Sosial, dan Budaya 
Pertama, seluruh warga Lingkungan Theresia atas segala partisipasi mereka, baik dalam bentuk sumbangan ide, maupun donasi serta keterlibatan langsung dalam kegiatan di lapangan.

Kedua, Bapak Indara Rahardja serta Bapak Agus Susanto yang telah berperan aktif dalam mengkoordinasikan kegiatan-kegiatan warga.

Ketiga, Ibu Agnes Baskoro selaku Ketua RT 1 dan Ibu Widiastuti selaku Ketua RW 9 di Kelurahan Pondok Pucung, yang telah menfasilitasi bagi warga Lingkungan Santa Theresia untuk ikut terlibat dalam mendukung kegiatan komunitas warga Baintaro Jaya.

\section{REFERENSI}

Fitrah, Elpeni, "Gagasan Human Security Dan Kebijakan Keamanan Nasional Indonesia" Jurnal INSIGNIA. Vol 2, No 1, April 2015. Diunggah dari file:///C:/Users/asus/Downloads/434-145-11821-10-20171222.pdf pada 3 Agustus 2020, Jam 08:36.

Harianto, Sugeng, Danang Tandyonomanu, Indah Prabawati, dan Indri Fogar Susilowati "Menggagas Indonesia Baru Melalui Pendidikan Multikultur dan Interaksi Antar Budaya", Prosiding Seminar Nasional Tahunan Fakultas Ilmu Sosial Universitas Negeri Medan Tahun 2017 Vol. 1 No. 1 2017, Hal. 215 - 221

Susetyo, Heru, "Menuju Paradigma Keamanan Komprehensif Berperspektif Keamanan Manusia dalam Kebijakan Keamanan Nasional Indonesia”. Lex Jurnalica Vol. 6 No.1, Desember 2008 